\title{
DIFFERENT COLORS AND POLITICALIDEOLOGY
}

\author{
Professor (Dr.) Mamta Chandrashekhar, \\ Department of Political Science
}

Govt. M.J.B .Girls P.G. College, Moti Tabela, Indore (M.P.) INDIA

\section{INTRODUCTION}

This research work based on the colorfulPolitics which existing in the different societies in the world. Everybody has a different thoughts and vision to see the world so there are different political ideologiesto represent a political party, either officially or unofficially. Political Parties in different countries with similar ideologies tend to use similar colours. They have long been associated with specific colors. This is largely due to the fact that politics became popular long before literacy did in the history of human being cultural development because the people couldn't read and even images could get complicated, political signs and signs in general, have to express something with different colors.India has always been exalted and remembered fondly as the country of different symbolic colors. To an outsider, its colorful culture, streets and stories seem like a page out of an ancient folk tale but there is a unity too in diversity. Different Colours, in essence, has been a large part of the Indian consciousness. Different parties come to rule with their owndifferent ideologieswith different colors. The symbolic colors of politics, there many colors, For example- Saffron- BJP ruled Centre and states,Tri color- Congress ruled states, Red Left parties ruled states. Another color-NCP ruled state (Jammu \&Kashmir) Every color has its own significance, own ideology, own thinking process, own style of functioning and own importance in political life. They may be like different flowers of different colors, but they all make a fabulous common garland-that is INDIA.

\section{OBJECTIVES}

To know the various colours and its political ideologies.

- To know significance of different colors.

- To know the different political parties in the world.

- To analyze the Impact of colours on political parties.

- To study the colours and the existing ideology.

- The other aim is to highlight the colorful system of politics.

\section{METHODOLOGY}

The study has made an in depth analysis of the "DIFFERENT COLORS AND POLITICAL IDEOLOGY". The research study is primarily based upon the official information obtained from the various official records, some non- governmental organizations. And every sincere effort has been made to collect the latest information. However, the scope of this study is limited to addressing"Different Colors and Political Ideology" only at various levels from the grassroots politicalIdeology to the state Ideology. The information for this baseline report was primarily collected from secondary sources. 
Art

\section{RESULT/ FINDINGS}

There are different colours of politics in the world which concern with ideologies, conceptual background, movements and political campaign.

\section{COLOUR CODE AND POLITICAL IDEOLOGIES}

We can see many colours in the life of politics, some are concern with material and some are with non-material things. There are some examples of different colors that come with ingrained political color associations:

\section{DIFFERENT COLORS OF POLITICS}

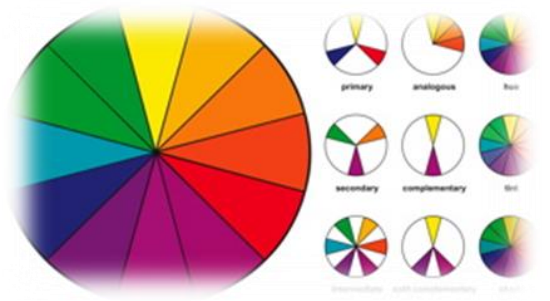

WHITE COLOUR: Psychologically, white colour automatically evokes notions of purity. Politically, white tends to be associated with pacifism. A predominantly white campaign sign can have this effect. White is today mainly linked to pacifism and in politics of the United Kingdom to independent politicians such as Martin Bell. Historically, it was associated with support for absolute monarchy, starting with the supporters of the Bourbon dynasty of France because it was the dynasty's colour. In Singapore, white is the colour associated with the People's Action Party, the party that has been in power, and dominating the Parliament, since the country's independence.

ORANGE COLOUR: In the past, orange color has been identified as one of the colors of royalty and it has since evolved in politics to represent religious political interests. Orange is the traditional colour of the Christian democrats, and it can also represent various kinds of populist parties. Such is the case in Austria, Germany, France, Portugal, Switzerland, Finland, Romania, Hungary, Slovakia, Czech Republic and Turkey.In Canada, orange is the colour of the New Democratic Party a social-democratic party. In Ukraine, orange was the colour of liberal groups that participated in the "Orange Revolution". This gave the colour orange a certain association with radical anti-authoritarian politics in some countries, and it has been used as such by groups and organizations in the Middle East.

GREEN COLOR: The color green means green politics, Green parties, and environmentalist movements worldwide. All over the world, it is the calling card color of the Green Party and means strong left wing politics and concern for environmental issues. Irish Nationalist and Irish Republican movements have used the colour green. Green has sometimes also been linked to agrarian movements, such as the Populist Party in the US in the 1890s, and the current-day Nordic Agrarian parties, as well as the National Party of Australia, a conservative party traditionally representing regional and agricultural interests. Green, considered the holy colour of Islam, is also used by some Islamists, such as Hamas. In Greece, green is the colour of the Panhellenic Socialist Movement, a social democratic party. In Taiwan, green often represents Democratic Progressive Party, the party and Taiwan independence movements have used the colour.In Europe, green represents European Federalism, particularly in the Federalist Flag.

BLACK COLOR: The Black tends to go back and forth in politics between association with fascism and anarchism. This color can be used to great effect in small amounts to provide shading and detail on print designs, but is traditionally the color choice of extreme politics that fall outside the realm of 


\section{INTERNATIONAL JOURNAL Of RESEARCH -GRANTHAALAYAH

democracy. Black color is primarily associated with anarchism and fascism Anti-clerical parties in the late 19th and early 20th centuries sometimes used the colour black in reference to the officials of the Catholic Church, because the cassock is usually black.In Germany and Austria, black is the colour historically associated with Christian-democratic parties.In Italy, black is the colour of fascism, because it was the official colour of the National Fascist Party.In Russia, black represented monarchism and nationalist movements such as the Black Hundreds before their defeat at the hands of the communists.In the Islamic world, black flags are sometimes use by Islamist groups

RED COLOR: Red is traditionally associated with socialism and communism. It symbolizes leftwing ideologies. However, in 2000, American media switched the Republican blue to red and Democrat red to blue. In spite of the Republican official color being blue and red being synonymous for communism. The colour red was chosen to represent the blood of the workers who died in the struggle against capitalism. All major socialist and communist alliances and organizations - including the First,Second, and Third Internationals - used red as their official colour. The association between the colour red and communism is particularly strong. Communists use red much more often and more extensively than other ideologies use their respective traditional colours.In Europe and Latin America, red is also associated with parties of social democracy, and often their allies within the labour movement. In the United Kingdom, Australia and New Zealand, red is also the colour of the labour movement. In Canada, red has always been associated with the Liberal Party of Canada, because one of its predecessors was the Parti rouge. (French for "Red Party)

BLUE COLOUR: It is a symbol of peace and hope. The dark blue, is usually associated with conservative parties, originating from its use by the Conservative Party in the United Kingdom. The field of the flag of the United Nations is light blue, chosen to represent peace and hope. It has given rise to the term bluewashing. In the United States, since the year 2000, the mass media have associated blue with the Democratic Party, the dominant center-left party. In 2010, the party unveiled a blue official logo. In the United States, blue is also often associated with organized labor, since it represents "blue collar" workers In South Africa, blue is usually associated with liberal and left-leaning political parties, the most popular being the Democratic Alliance. In India, blue is associated with the Dalit movement. Turquoise is used to represent Turkic peoples and Turkic heritage.Kuomintang (KMT) is the largest conservative party of Republic of China.

BROWN COLOR: Brown color has been associated with Nazism, because the Sturm abteilung (SA) were called "brown shirts." In Europe and elsewhere, the colour brown is sometimes used to refer to fascists in general.

GREY COLOR: Grey color is sometimes used by parties that represent the interests of pensioners and senior citizens, such as "The Greys" in Germany. It can also be used to refer to reactionary movements, due to its association with the Confederate States of America.Grey is often used to represent Independent politicians.

PINK COLOR: Pink color is seen as a softer, less aggressive version of red. It is sometimes used by Social Democrats, such as in France and Portugal. The more traditional colour of social democracy is red (because social democracy is descended from the democratic socialist movement), but some countries have large social-democratic parties alongside large socialist or communist parties, so that it would be confusing for them all to use red. In such cases, social democrats are usually the ones who give up red in favour of a different colour. Pink is the color of the feminist party Feminist Initiative in Sweden too.

YELLOW COLOR: This colour most commonly associated with liberalism. It is the official colour of the Alliance of Liberals and Democrats for Europe, as well as being the colour of liberal parties in Germany, Romania, Estonia and the United Kingdom (the Liberal Democrats). Yellow is also often used to represent libertarianism. Yellow is also associated with Judaism and the Jewish people, although this 


\section{INTERNATIONAL JOURNAL Of RESEARCH -GRANTHAALAYAH

Art

may be seen negatively and since 1945, the blue Star of David is preferred. In Asia, yellow may be used to represent monarchies. For instance, in Thailand, yellow represents King Bhumibol. It was also the colour of the pro-monarchy Panchayat system in the Kingdom of Nepal.

SAFFRON COLOR: The saffron colour denotes renunciation of disinterestedness. In India our leaders must be indifferent to material gains and dedicate themselves to their work, it is traditionally associated with Hinduism, Hindutva and the Hindu nationalist movement Saffron was chosen because in Hindu Sanatana Dharma, the deep saffron colour is associated with sacrifice, religious abstinence, quest for light and salvation. Saffron or "Bhagwa" is the most sacred colour for the Hindus and is often worn by Sanyasis who have left their home in search of the ultimate truth

\section{COLORS IN POLITICAL CAMPAIGN}

It is a fact that different colours are very important in political campaign. During the campaign colour express the ideology of a political party. All Political parties have long been associated with specific colors. This is largely due to the fact that politics became popular long before literacy did in the history of human cultural development. Because the people couldn't read and even images could get complicated, political signs and signs in general way too.

Even if a party campaign chooses to go with the standard red and blue, there are still several factors to take into account. Red and blue color comes in an almost infinite variety of shades. Reds can range from pinks and mauves to deep burgundies and maroons. Blues can go from powder and periwinkle to midnight and navy. The same is true for all other colorsbecause the colors chosen for a campaign is a fundamental part of the political marketing and political psychology.

The pressure is on for campaign managers to build up a candidate's web presence. In fact, the web has become such a focus that you may choose your campaign colors with online visibility in mind. However, make sure that colors suit the party ideology printed campaign signs, as well.

\section{THE SKIN COLOR AND POLITICS}

This study considers for an imaginative and radical politics against all forms of racism. All form of discriminations is harmful for human being. It is a violation of human rights but unfortunately, existence of race discrimination in the world of political colors, harassed the black skin people. No one can forget the train incident which faced by Gandhi ji in South Africa due the color of skin. There was a thinkingof superior color- white. It thought made a ideology in Europe and Africa for a long period. That ideology of race as a symbol of inherent human attributes.

\section{COLORS OF FLAG AND INDIA NATIONAL MOVEMENT}

In 1921Gandhi first proposed a flag to the Indian National Congress. The flag was designed by Pingali Venkayya. In the Centre was a traditional spinning wheel, symbolizing Gandhi's goal of making Indians self-reliant by fabricating their own clothing. The design was then modified to include a white stripe in the Centre for other religious communities, and provide a background for the spinning wheel. Subsequently, to avoid sectarian associations with the colour scheme, saffron, white and green were chosen for the three bands, representing courage and sacrifice, peace and truth, and faith and chivalry respectively. A few days before India became independent on 15 August 1947, the specially constituted Constituent Assembly decided that the 


\section{INTERNATIONAL JOURNAL Of RESEARCH -GRANTHAALAYAH \\ A knowledge Repository}

Art

flag of India must be acceptable to all parties and communities. So, a modified version of the Swaraj flag was chosen; the tricolour remained the same saffron, white and green. However, the charkha was replaced by the Ashoka Chakra representing the eternal wheel of law.

The philosopher Sarvepalli Radhakrishnan, who later second President of India clarified the adopted flag and described its significance as follows - "Bhagwa or the saffron colour denotes renunciation of disinterestedness. Our leaders must be indifferent to material gains and dedicate themselves to their work. The white in the Centre is light, the path of truth to guide our conduct. The green shows our relation to (the) soil, our relation to the plant life here, on which all other life depends. The "Ashoka Chakra" in the Centre of the white is the wheel of the law of dharma. Truth or satya, dharma or virtue ought to be the controlling principle of those who work under this flag. Again, the wheel denotes motion. There is death in stagnation. There is life in movement. India should no more resist change, it must move and go forward. The wheel represents the dynamism of a peaceful change".

\section{CONCLUSIONS}

The political life is colorful. It has many dimensions, ideology and working style. Due to the different colors political parties become unique. So, all colors are very useful in politics.

\section{REFERENCES}

1 Electoral Commission (27 November 2007). "The Family Party - Applications to register party name and logo". Retrieved 20 June 2014.

2 Electoral Commission (17 December 2007). "The Family Party registered, logo declined". Retrieved 20 June 2014

3 "Historic Election Results". The U.S. National Archives and Records Administration. Retrieved 2 November 2012.

4 "Handbook of Texas Online - REDS AND BLUES". Tshaonline.org. Retrieved 17 October 2011.

5 Kathy Russell, Midge, Ph.D. Wilson, Ronald E. Hall.The Color Complex: The Politics of Skin Color Among African Americans Hardcover - Import, Nov 1992

6 Rowe, Tara A. (13 January 2005). "The Political Game: The Red and Blue State Phenomenon". Politicalgame.blogspot.com. Retrieved 17 October 2011.

7 "Strong Showing for Santos in Colombia's First round". As-coa.org. 31 May 2010. Retrieved 17 October 2011.

8 Vron Ware, Out of Whiteness - Color, Politics \& Culture Paperback-Import, 12 Mar 2002

9 Véronique Bénéi (2005). Manufacturing Citizenship: education and nationalism in Europe, South Asia and China. Routledge. ISBN 0-415-36488-4. 